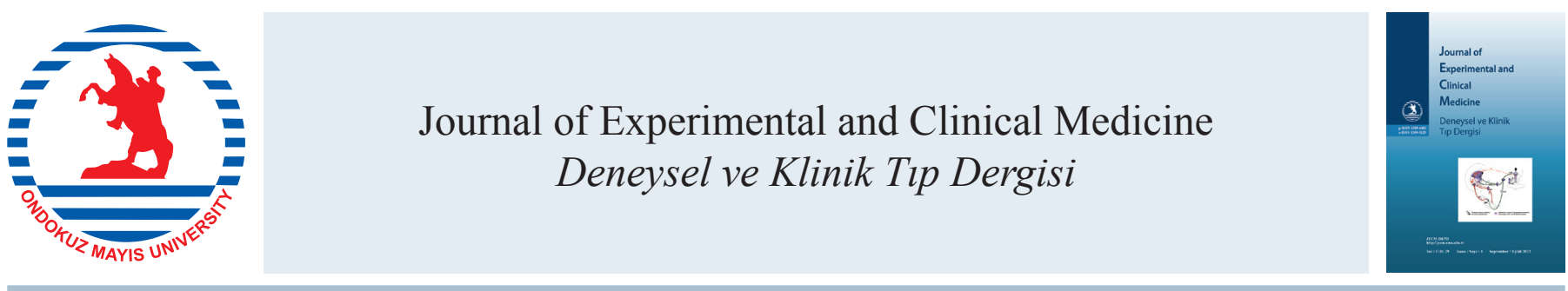

Case Report

doi: $10.5835 /$ jecm.omu.29.03.018

\title{
Gunpowder injury to the cornea and the lens
}

Barut ile oluşan kornea ve lens yaralanması

Fahrettin Akay*, Yıldıray Yıldırım

Department of Ophthalmology, Izmir Military Hospital, İmir, Turkey

\begin{tabular}{|c|c|}
\hline \multicolumn{2}{|c|}{ ARTICLE INFO } \\
\hline \multicolumn{2}{|c|}{ Article History } \\
\hline Received & $10 / 04 / 2012$ \\
\hline Accepted & 15 / $05 / 2012$ \\
\hline
\end{tabular}

\section{* Correspondence to:}

Fahrettin Akay

İzmir Military Hospital,

Department of Ophthalmology

İzmir, Turkey

e-mail: drfakay@yahoo.com

\section{Keywords:}

Gunpowder injury

Lens

Cornea

Cataract

Trauma

Anterior segment

\section{Anahtar Kelimeler: \\ Barut hasarı}

Lens

Kornea

Katarakt

Travma

Ön segment

\section{ABSTRACT}

To report a case of gunpowder injury to left eye with both superficial and deep seated corneal-conjonctival multiple gunpowder particles. A 30-year-old noncommicent officer injured by the explosion of a heavy machine gun loaded with a big caliber bullet during the battle training. He suffered from the multiple particles of nonactivated gunpowder to his face and left eye. His visions were 20/20 in the right eye and 20/32 in the left eye with Snellen visual acuity chart. Multiple gunpowder particles and tattooing of skin were seen in the left periorbital region. Slit lamp examination revealed mild subconjunctival hemorrhage, mild conjunctival chemosis, multiple black sphere shaped gunpowder particles embedded in the lid margins, conjunctiva and corneal epithelium of left eye. At the central cornea there was a closed perforation and a paracentral crystalline lens perforation. The slit lamp examination also revealed an intralenticular foreign body. Multiple subconjunctival and superficial corneal gunpowder particles were removed using a 28-gauge needle. Deep stromal particles were left in their place, as there was a high risk of corneal perforation. There was no cataract formation in the lens. At the end of the sixth month, a few subconjunctival particles, a few deep stromal particles and an intralenticular particle in the left eye remained without any inflammatory reaction and cataract formation

J. Exp. Clin. Med., 2012; 29:249-251

\section{ÖZET}

Multipl barut tanecikleri ile sol gözden derin ve yüzeyel yerleşimli korneal-konjonktival yaralanma vakası rapor edildi. 30 yaşındaki bir astsubay eğitim sırasında uçaksavar mermisinin patlaması sonucu yaralanmıștır. Sol gözü ve yüzünde aktive olmamıș barut parçaları bulunmaktaydı. Görme düzeyleri Snellen eşeline göre sağ gözde 20/20 sol gözde 20/32 düzeyindeydi. Sol periorbital bölgede multipl barut parçaları ve tatuaj izlenmekteydi. Yarık lamba ile yapılan muayenede hafif subkonjonktival hemoraji, kemosiz, kapak kenarlarına, kornea ve konjonktivaya yapışık küre şekilli multipl siyah barut parçaları izlenmekteydi. Santral korneada kapalı perforasyon ve parasantral lens perforasyonu izlenmekteydi. Lens içerisinde yabancı cisim mevcuttu. Multipl subkonjonktival ve yüzeyel barut parçaları 28 gauge iğne ile temizlendi. Korneal perforasyon nedeni ile derinde yerleşik olan partiküller çıkarılmadı. Lenste katarakt oluşumu izlenmedi. Altı aylık takibin sonunda intralentiküler, subkonjonktival ve korneal barut parçalarının herhangi bir inflamatuar reaksiyona sebebiyeti ve katarakt oluşturduğu gözlenmemiştir. J. Exp. Clin. Med., 2012; 29:249-251

\section{Introduction}

Gunpowder has been used since ancient times in firearms and explosives. Gunpowder was invented by Chinese alchemists in the 9 th century. It was made by mixing elemental sulfur (3-14\%), charcoal (12-0\%) and saltpeter $(70 \%)$ (potassium nitrate or sometimes sodium nitrate). When it is activated the expanding gases, nitrogen and carbon dioxide, it provides the propelling action. In 17 th century smokeless gunpowder was invented since then it has largely replaced black gunpowder. It comprises mainly of nitrocellulose and cut with a guillotine to flakes of the desired size.

Military personnel could be injured from gunpowder during routine traning or in a conflict. After explosion of a firearm, residue of gunpowder with high kinetic energy could harm the different parts of human body as well eye. Ocular injury covers a broad range of severity, from a small corneal 
epithelial abrasion to the more severe penetrating and globe ruptures.

Gunpowder trauma alone to the eye has been rarely reported (Dreizen and Stulting, 1985; Hanke et al., 1987; White et al., 1988; Amin and Keenan, 2007; Kotagiri et al., 2008). We report a case of gunpowder injury to left eye with both superficial and deep seated corneal-conjonctival multiple gunpowder particles, an intralenticular particle and tattooing of the skin.

\section{Case}

A 30-year-old noncommicent officer injured by the explosion of a heavy machine gun loaded with a big caliber $(7.62 \mathrm{~mm})$ bullet during the battle training (Fig. 1).

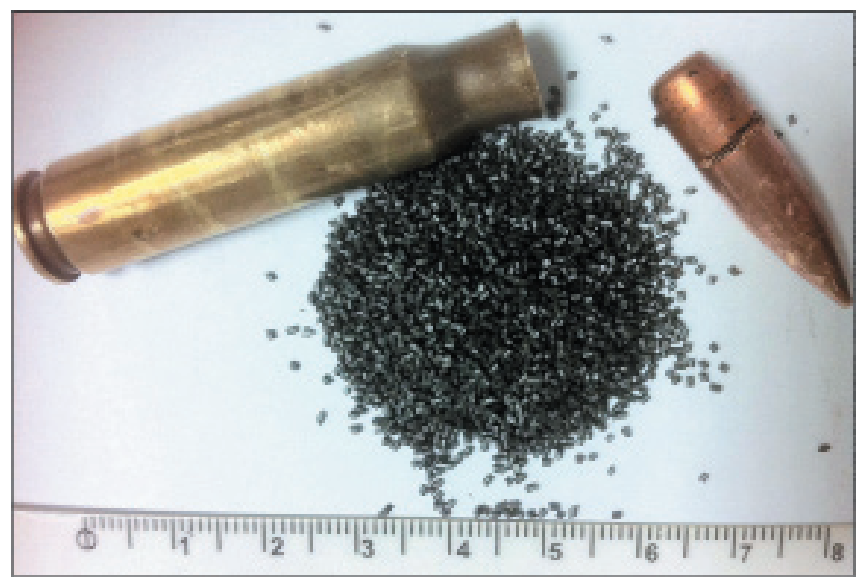

Fig. 1. Heavy machine gun bullet with big calibre $(7.62 \mathrm{~mm})$ and gunpowder particles.

He suffered from the multiple particles of nonactivated gunpowder to his face and left eye. After complete examination of the body, the ocular examination was performed. On the examination, his vision, using the Snellen visual acuity chart, was 20/20 in the right eye and 20/32 in the left eye. The examination with penlight of the right and left eye pupil were round, about $3.5 \mathrm{~mm}$ in diameter constricting to about $2.5 \mathrm{~mm}$ on direct light exam. There was no afferent pupillary defect. Multiple gunpowder particles and tattooing of skin was seen in the left periorbital region. Slit lamp examination revealed mild subconjunctival hemorrhage, mild conjunctival chemosis, a paracentral crystalline lens perforation and multiple black sphere shaped gunpowder particles embedded in the lid margins, subconjunctival area and in the corneal epithelium of left eye (Fig. 2).

Gunpowder particles were localized in the left cornesuperficially and the deep stromal layer nearly touching endothelium. Corneal edema and epithelium defect was seen. It was assumed that the blast impact resulted in corneal edema due to endothelial damage. At the central cornea there was a closed perforation. The Seidel test with a moistened fluoresceine strip (Fluor-1-Strip, fluoresceine sodium 1mg, Bausch \& Lomb) was negative. The slit lamp examination also revealed an intralenticular foreign body what was probably a nonactivated gunpowder particle (Fig. 2). The other parts of lens were clear. The dilated fundoscopy revealed clear vitreous and normal retina.

Orbital computerized tomography (CT) showed a radioopaque intralenticular foreign body in left eye; otherwise

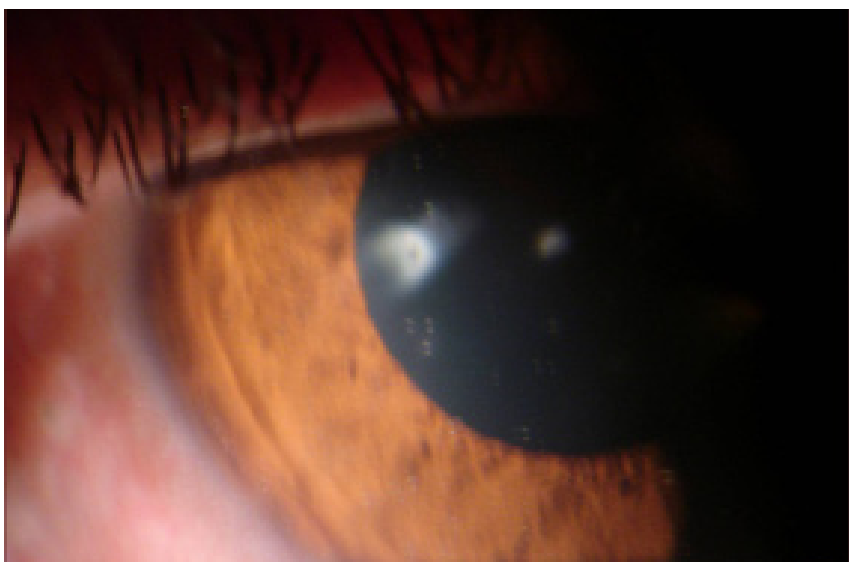

Fig. 2. Paracentral cristallin lens perforation, intralenticular gunpowder particle, multiple black gunpowder particles in the subconjunctival area and in the corneal epithelium of left eye.

all the other orbital structures were normal. There were no complaints related to the right eye. Examination of the anterior and posterior segments of the right eye was normal.

The patient was prepared for local anesthesia and was informed for the operation. Immunization for tetanus was performed. In the operation room, skin debridement was performed and gunpowder particles removed which localized superficially. The left eye was carefully prepped with 5\% betadine and a sterile eye drape was placed. Multiple subconjunctival and superficial corneal gunpowder particles were removed using a 28-gauge needle. Deep stromal particles were left in their place, as there was high risk of corneal perforation. There was no cataract formation in the lens.

At the end of the procedure, topical antibiotics Vigamox ${ }^{\circledR}$ (Moxifloxacin hydrochloride $0.5 \%$, Alcon) and steroids (fluorometholone $0.1 \%$, FML, Allergan) were administered.

The patient was discharged from the hospital five days after the surgery and a clinic visit was scheduled for the following day. The patient was closely followed over the next one month. There was no reaction in the lens and anterior chamber. At the end of second month, best corrected visual acuity in left eye was 20/25. At the end of the sixth month, few subconjunctival particles, some deep stromal particles and intralenticular particles in the left eye remained without any inflammatory reaction and cataract formation. There was only a minimal opacity around the nonactivated gunpowder particle (Fig. 3).

\section{Discussion}

Firearm related eye injuries cover a broad range of severity, from a small corneal epithelial abrasion to the more severe penetrating and globe rupture injuries. In all cases of penetrating ocular injuries, close daily follow-up is required to monitor progress and identify any sign of complications (Newman and Russo, 1998).

According to the previous reports, retained ocular gunpowder particles are well tolerated by the eye, and do not need removal unless there is a specific indication (Dreizen and Stulting, 1985; Hanke et al., 1987; White et al., 1988; Amin and Keenan, 2007; Kotagiri et al., 2008).

Nitrocellulose is the main part of the gunpowder and its degradation products are nitrates and carbons have no toxic effect. Furthermore, extracellular localized gunpowder par- 


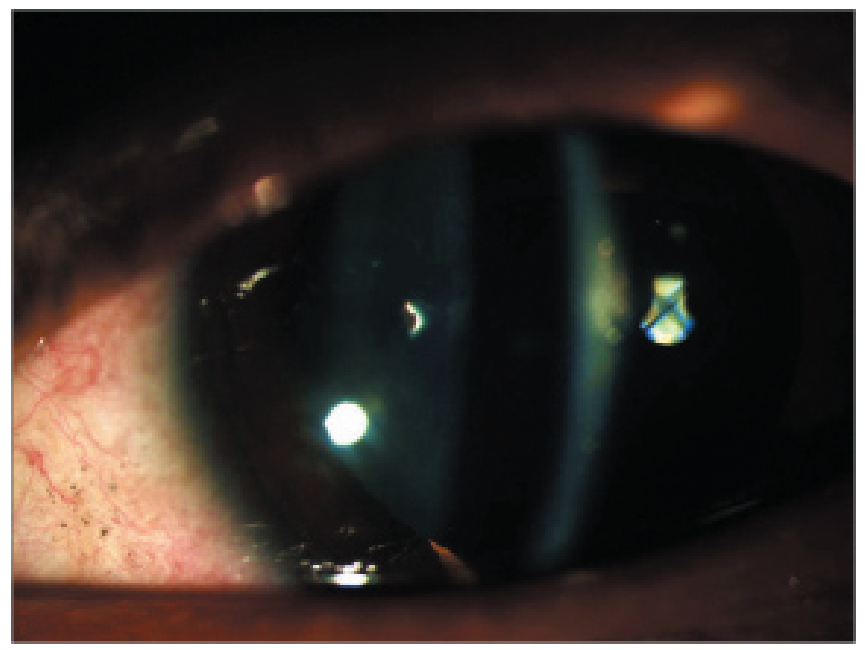

Fig. 3. At the end of the sixth month, few subconjunctival particles, some deep stromal particles and intralenticular particles remained without any inflammatory reaction. ticles cause no inflammatory reaction (White et al., 1988). Our case was followed for six months and we could not see any inflammatory reactions in conjunctiva and anterior chamber. The patient had complaints because of foreign bodies at the end of six month. Cataract development was reported in a case after 3 months without penetration (White et al., 1988). Although our case has an intralenticular particle, no cataract development was seen at the end of six month. We assess that gunpowder particles are well tolerated in human crystalline lens.

Finally, as the same previous reports, our clinical observations and histological findings show that retained ocular gunpowder particles are well tolerated by the ocular tissue, and there is no need to remove unless there is a specific indication.

\section{REFERENCES}

Amin, K., Keenan, J., 2007. Ocular gunpowder injury. Eye. 21, 119-120.

Dreizen, N.G., Stulting, R.D., 1985. Ocular gunpowder injuries. Am. J. Ophthalmol. 100, 852-853.

Hanke, C.W., Conner, A.C., Probst, E.L.Jr., 1987. Blast tattoos resulting from black powder firearms. J. Am. Acad. Dermatol. 17, 819-825.

Kotagiri, A.K., Sundaram, V., Khandwala, M., Teimory, M., 2008. Gunpowder injury to the eye. Clin. Exp. Ophthalmol. 36, 190-191.

Newman, T.L., Russo, P.A., 1998. Ocular sequelae of BB injuries to the eye and surrounding adnexa. J. Am. Optom. Assoc. 69, 583-590.

White, W.N., Preston, R., Morgan, C.M., 1988. Retained ocular gunpowder. Am. J. Ophthalmol. 106, 762-763. 